\section{PINE SHOOT BEETLES}

A $\mathrm{N}$ interesting account of pine shoot beetles has recently been published by Dr. Leon Ossowski (Scot. Forest. J., 55. Part 2; 1941; Douglas and Foulis, Edinburgh). The author states that any forestry publication, British, Polish, German or Russian, is likely to contain an article on bark beetles and more especially the pine shoot beetles, which proves the destructive nature of these pests. In spite of many natural enemies the two pine shoot beetles are very plentiful, largely due, as Dr. Ossowski correctly states, to the usual technique of planting, "for planting concentrated in one year or on a single species gives a breeding ground for the beetles. Where we have natural regeneration and plantations of different ages and different species the beetles are rarely met with."

Equally correctly the author advocates that, in future, planting should not be confined to Scots pine,

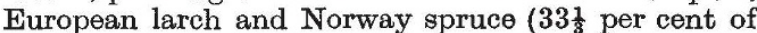
each) but that 30 per cent or even half of a plantation should consist of deciduous trees. It is an undoubted fact that in those temperate countries where considerable tracts of conifers either pure or mixed have been planted, sooner or later the areas have been visited by serious epidemics of pests-frequently the various bark beetles. There are others, for example, the plague of the pine noctuid (Panolis piniperda Panz) in Brandenburg and Pomerania in Germany which laid waste thousands of hectares of coniferous woods during 1921-25; or the great devastation in the spruce forests in the Vosges (1903-05) by bark beetles. In spite of the well-known examples of widespread attack and heavy losses the lesson is difficult to leam apparently-for the pure conifer plantation is still being planted on a wide scale in temperate climates.

The author discusses some of the well-known methods of combating attacks and incidentally affords an interesting side-light on his own country, Poland.

"A striking example of the motto 'Back to Nature" is given by the woodlands of my own country. While in West Poland the woods are mainly coniferous, those of the North and North-east Poland are of a more mixed type with natural regeneration. Between 1920 and 1939 there were in West Poland two attacks of pine noctuid (1922-1925 and 1931-1933), two of the pine moth (Dendrolimus pini) and the pine looper (Bupalus piniaria) and one of the nun moth (Liparis monacha). The damage done by the insects was enormous and, so far as I can remember, through the noctuid plague of $1922-25$ about 250,000 hectares of coniferous plantations must have been ruined, and in 1931-33 it cost $3,500,000$ zloty $(£ 140,000)$ to combat the evil. In the forests of North and Northeast Poland, on the other hand, there were no great disasters from insect pests to record, and if here and there destructive insects appeared the trouble was only local and the loss not very great. As already stated, mixed plantations and a combination of tree groups of different ages give the best defence against bark beetles and destructive insects in general."

Research and experience are showing that much the same general rule applies to the broad-leaved species of fine timbers in the tropical and sub-tropical forests. It is becoming equally plain that the ordinary practising forester (or agriculturist, for that matter) finds it difficult to appreciate the fact until he faces a disaster.

\section{FORTHCOMING EVENTS}

(Meeting marked with an asterisk is open to the public)

\section{Saturday, February 28}

ROYAL SANITARY INSTITUTE (at the Nuffield Institute of Clinical Research, Oxford), at 10 a.m.-Mr. H. H. Crawley: "The Storage of Emergency Drinking Supplies"; Mr. Stewart Smith: "Administration of the Government Evacuation Scheme".

NuTRiTion SOcIETy (at the London School of Hygiene and Tropical Medicine, Keppel Street, London, W.C.1), at 10.30 a.m.- Conference on "Food Production and Distribution in relation to Nutritional Needs"” (Speakers: Sir John Orr, F.R.S., Dr. N. C. Wright, Mr. E. T. Halnan, and Sir John Russell, F.R.S.)

Monday, March 2

ROYAL GEOGRAPHICAL SOCIETY (at Kensington Gore, London, S.W.7), at 5 p.m. - Capt. G. S. Andrews: "Projects for the Alaska Highway Route".

\section{Tuesday, March 3}

ROYAL INSTITUTION (at 21 Albemarle Street, London, W.1), at 2.30 p.m.-Sir Lawrence Bragg, F.R.S.: "Metals", 1: "Metal

Wednesday, March 4

ROYAL Society of ARTS (at John Adam Street, Adelphi, London W.C.2), at 1.45 p.m. -Mr. Llewellyn S.-Lloyd : "Modern Science and Musical Theory',

Thursday, March 5

Town and Countrx Planning Association (in the Dome Lounge, Dickins and Jones, 224 Regent Street, London, W.1), at 1.20 p.m. Rt. Hon. Sir Montague Barlow, Bart.: "Decentralization and the Location of Industry"

\section{Friday, March 6}

Physidal Soctery (OPTTCAL GrodP) (at the Science Museum, Exhibition Road, London, S.W.7), at 11.15 a.m.-First Genera (Business) Meeting; at 11.30 a.m.-Dr. W. M. Hampton :"Problems relating to Optical Glass"; at $3 \mathrm{p} . \mathrm{m}$. (in the Small Physics Lecture Theatre of the Imperial College, Imperial Institute Road, London, S.W.7)-Mr. R. J. Bracey: "A Multi-Purpose Collimator"; Mr. J. W.

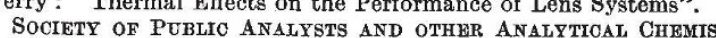
at the Chemical Society, Burlington House, Piccadilly, London, W.1), at 4 p.m.-Annual General Meeting; at 4.45 p.m.-Prof. J. W. Munro: "Entomology of Commerce".

Institution of Mechanical Engineers (at Storey's Gate, London, S.W.1), at 5.30 p.m.Mr. B J Tams: "The Operation of the Mech, anical Engineering Section of the Central Register in War Time".

\section{Saturday, March 7}

GEologists' Assocration (at the Geological Society of London, Burlington House, Piccadilly, London, W.1), at 2.30 p.m.-Mr. Subjects from the 16th Century" (Presidential Address).

\section{APPOINTMENTS VACANT}

Appuroamons are invited for the following appointments on or before the dates mentioned :

Gradoate Lecturer in Enginearing-The Principal and Clerk to the Governing Body, Wigan and District Mining and Technical College, Wigan (March 7 ).

Lecturkr in Civil and Mechanical Engineering-The Secretary, Northampton Polytechnic, St. John Street, London, E.C.1 (March 16). Soinntifio Assistant (woman not liable for National Service)The Deputy Director, Imperial Bureau of Pastures and Forage Crops, Agricultural Research Building, Penglais, Aberystwyth (March 21).

Professor of EDUCATION-The Registrar, University College of Swansea, Singleton Park, Swansea (April 11).

Assistant Mechanidal E.veineer for the Electrical Branch of the Nigerian Government Public Works Department-The Secretary, Anne's Chambers, London, S.W.1 (quoting reference O.N.C.793).

\section{REPORTS and other PUBLICATIONS} (not included in the monthly Books Supplement)

\section{Great Britain and Ireland}

Proceedings of the Royal Society of Edinburgh. Section B (Biology). Vol. 61, Part 2, No. 14: Quantitative Characters of the Growth and Development of a Paurometabolous Insect, Dixippus (Carausius) mornsus Br. et Redt. 1: The Loss of Water in relation to Ecdysis. By Dr. Beverley N. Smallman. Pp. 167-185. 1s. 6d. Vol. 61, Part 2, No. 15: A Simple Apparatus for the Direct Determination or the tiona tions on Artictally lnduced Heat in Inmature Guinea Pigs. By Dr. P. Bacsich and Or. G. M. W yburn. Pp. $188-196+2$ plates. $9 d$. 